\title{
Genetic parameters for type traits in Holstein cows in Brazil
}

\author{
Rafael Viegas Campos ${ }^{1}$, Jaime Araujo Cobuci ${ }^{1}$, Claudio Napolis Costa², José Braccini Neto ${ }^{1}$ \\ ${ }^{1}$ Universidade Federal do Rio Grande do Sul, Departamento de Zootecnia. \\ ${ }^{2}$ Embrapa Gado de Leite.
}

\begin{abstract}
Data from 26,558 Holstein cows in 802 herds were used to estimate genetic, residual and phenotypic parameters for 22 type traits. The model included the fixed effects of herd-year, period of classification, classifier, stage of lactation and age of cows at calving (covariate) and random genetic and residual effects. Heritability for type traits ranged from 0.10 to 0.39 . The genetic variability in these traits suggested the possibility for moderate genetic gains through selection. The phenotypic correlations were moderated, mainly in the section conformation. Genetic correlations between type traits ranged from -0.44 to 0.85 . High genetic correlations indicated that breeding programs could be successful without including all type traits. The selection for the final score at the expense of other traits must be performed with restraint, because in the long term, this may promote undesirable changes in some type traits.
\end{abstract}

Key Words: (co)variance components, dairy cattle, genetic correlations, heritability, REMLF90, selection

\section{Introduction}

The selection process for Holstein cows in Brazil prioritizes production traits due to a payment system that favors, in most dairy products, the credited volume of production (Sbrissia, 2005). Several studies (DeGroot et al., 2002; Peres-Cabal et al., 2006; Lagrotta et al., 2010) have shown that the emphasis of selection for increased milk production may result in a decrease in the merit of some traits of type and influence the health of cows, resulting in decreased productive life (longevity) and involuntary culling by factors such as non-productive systems related to udder, reproductive, structural and locomotive issues. In this context, type traits have a direct influence on the management of cows and are related to the profitability of the herd (Berry et al., 2005; Darili et al., 2008), suggesting the importance of studies aimed at reducing involuntary culling and selection for resistant animals.

Recently, type traits have been associated with productive traits and, through selection indexes, they have been used as selection criteria in various countries (Pribyl et al., 2004; Miglior et al., 2005). Some studies involving the estimation of genetic parameters for type traits have been carried out in herds in the U.S., Canada, France, Spain and Iran (Short \& Laulor, 1992; Klassen et al., 1992; Rupp \& Boichard, 1999; Peres-Cabal \& Alenda, 2002; Darili et al., 2008). In Brazil, a few studies have been developed for this purpose; among them, studies conducted by McManus \& Saueressig (1998), Freitas et al. (2002) and
Esteves et al. (2004a) in the Holstein breed and by Renno et al. (2003) and Lagrotta et al. (2010) in the Brown-Swiss and Gir breeds, respectively.

Knowing the estimates of (co)variance of type traits is important for the implementation of selection programs. Considering the economic importance of the breed and the lack of studies involving the national herd, the objective of this study was to simultaneously estimate heritability and genetic, residual and phenotypic correlations, between 21 linear type traits plus the final score for the Holstein cow breed in Brazil.

\section{Material and Methods}

The present study initially used the records of 71,282 linear classifications for type traits in Holstein cows, collected between 1994 and 2004 by technicians of the Service Control Linear Classification of Associação Brasileira de Criadores de Bovinos da Raça Holandesa (ABCBRH). The classification system is based on direct and/or visual measurements of the morphology of cows, expressed on a rating scale ranging from 1 (one) to 9 (nine) points.

The linear classification system used by $\mathrm{ABCBRH}$ includes 21 type traits, divided into seven sections: 1 . Conformation (stature, top line, weight, chest width, body depth, loin strength); 2. Rump (angle and width); 3. Legs and feet (foot angle, bone quality, side view of rear legs); 4 . Front udder (fore udder attachment, fore teat placement and 
teat length); 5. Rear udder (height, width and placement of the teats of the rear udder); 6. Mammary system (depth, udder texture and udder cleft); and 7. Dairy form (angularity), as well as the final score, which expresses the balance between the sections.

To improve the consistency of the structure of the database, the records of linear classification were edited to parity (first to fifth), the year of classification and calving (1994-2004) and the final score (53-90 points). In the rare cases where the cows had more than one classification over the productive life, one (the last and best) classification was considered for the cow, which was held between the first and tenth month of lactation. Groups of contemporary animals (herd-year of classification) that did not contain at least two classifications and at least two progeny from a bull in two herds were eliminated.

After applying these restrictions, 26,558 records remained with linear classifications for cows aged between 18 and 115 months, including the daughters of 980 bulls, classified in 802 herds.

A multiple trait model was used, including fixed effects of the contemporary group $(2,485)$, the period of classification (1 = January, February, March; 2 = April, May, June; 3 = July, August, September; 4 = October, November, December), classifier (16), the stage of lactation (first to tenth month) and age at calving (18 to 115 months) as linear and quadratic covariates and the animal and residual random effects. The relationship matrix contained information from the animal, sire and dam, totaling 44,761 animals.

In matrix notation, the model used can be described as follows:

$\left[\begin{array}{c}y_{1} \\ \vdots \\ y_{22}\end{array}\right]=\left[\begin{array}{ccc}\boldsymbol{X}_{1} & 0 & 0 \\ 0 & \ddots & 0 \\ 0 & 0 & \boldsymbol{X}_{22}\end{array}\right] \cdot\left[\begin{array}{c}b_{1} \\ \vdots \\ b_{22}\end{array}\right]+\left[\begin{array}{ccc}\boldsymbol{Z}_{1} & 0 & 0 \\ 0 & \ddots & 0 \\ 0 & 0 & \boldsymbol{Z}_{22}\end{array}\right] \cdot\left[\begin{array}{c}a_{1} \\ \vdots \\ a_{22}\end{array}\right]+\left[\begin{array}{c}e_{1} \\ \vdots \\ e_{22}\end{array}\right]$,

in which $y$ is the vector that includes each of the 22 type traits; $b$ is the vector of fixed effects; $a$ is the vector of animal random genetic effects; $e$ is the vector of random residual effects; and $X$ and $Z$ are incidence matrices relating the observations of 22 traits of the fixed and random effects of the animal, respectively.

It is assumed that:
$\left[\begin{array}{c}a_{1} \\ \vdots \\ a_{22} \\ e_{1} \\ \vdots \\ e_{22}\end{array}\right]=\left[\begin{array}{cccccc}g_{1,1} \boldsymbol{A} & \ldots & g_{1,22} \boldsymbol{A} & 0 & \ldots & 0 \\ \vdots & \ddots & \vdots & \vdots & \ddots & \vdots \\ g_{22,1} \boldsymbol{A} & \ldots & g_{22,22} \boldsymbol{A} & 0 & \ldots & 0 \\ 0 & \ldots & 0 & r_{1,1} \boldsymbol{I} & \ldots & r_{1,22} \boldsymbol{I} \\ \vdots & \ddots & \vdots & \vdots & \ddots & \vdots \\ 0 & \ldots & 0 & r_{22,1} \boldsymbol{I} & \ldots & r_{22,22} \boldsymbol{I}\end{array}\right]$ in which $g_{i j}$ are the matrix elements $\mathrm{G}$, matrix of the (co)variance additive genetic with each element defined as: $g_{1,1}$ is the additive genetic variance for the direct effects of trait $1 ; g_{1,22}=g_{22,1}$ is the covariance additive between the $1 \mathrm{st}$ and 22nd trait; $g_{22,22}$ is the genetic variance additive effects of trait $22 ; A$ is the numerator relationship matrix; $r_{i j}$ are the elements of matrix $R$, the matrix of (co)variance of residual effects with each element defined as: $r_{1,1}$ is the residual variance for trait $1 ; r_{1,22}=r_{22,1}$ is the residual covariance between the 1 st and 22 nd trait; $r_{22,22}$ is the residual variance for the trait 22 ; $I$ is the identity matrix which implies the independence of errors with the same variance.

The (co)variance components were estimated by restricted maximum likelihood using the application REMLF90 (version 1.55), developed by Misztal (2001). The convergence criterion was set at $10^{-11}$.

The analysis processing for the joint estimation of the components of (co)variance was performed in the operating environment SGI Altix-1350, provided by Centro Nacional de Processamento de Alto Desempenho em São Paulo (CENAPAD - SP).

\section{Results and Discussion}

The average values for 21 linear type traits ranged between 4.36 and 7.09, indicating how the cows tended toward scores closer to or farther from the ideal recommended for the breed (Table 1).

The adoption of a scale of 1 to 9 points means that the average scores for the ideal linear type traits are above 5 . However, for some traits, such as the rump angle, side view of rear legs and udder depth, the highest score of the animals was not superior as an intermediate score was most desirable in this case.

Since most studies related to type traits in Holstein cows were carried out in countries in North America and Europe (Misztal et al., 1992; Short \& Lawlor, 1992; Wiggans et al., 2004), the Brazilian herd may have been influenced by the high use of imported semen from these countries.

Examples are high scores for traits related to body size (Misztal, 1992; Short \& Lawlor, 1992), especially stature. For many years, it was believed that more productive cows were those of a larger size; however, Berry et al. (2005), when evaluating Irish herds, found that this is not strictly true, since smaller cows can produce as efficiently as those of greater size.

Mean scores of udder depth, rear udder width and rear udder height traits (Table 1) were lower than the scores reported by Freitas et al. (2002) in a study conducted in Brazil with Holstein herds in the state of Minas Gerais.

The average score observed for the final score trait (81.12) is in accordance with the minimum standard set as 
Table 1 - Means, standard deviations and variance components estimated for type traits in Holstein cows

\begin{tabular}{|c|c|c|c|c|c|}
\hline \multirow[b]{2}{*}{ Traits } & \multirow{2}{*}{$\begin{array}{c}\text { Average } \\
\text { (standard } \\
\text { deviation) }\end{array}$} & \multirow{2}{*}{$\begin{array}{l}\text { Ideal } \\
\text { score }\end{array}$} & \multicolumn{3}{|c|}{ Variance componen } \\
\hline & & & $\hat{\sigma}_{a}^{2}$ & $\hat{\sigma}_{e}^{2}$ & $\hat{\sigma}_{p}^{2}$ \\
\hline \multicolumn{6}{|c|}{ Conformation / Capacity } \\
\hline Stature & $7.09(1.37)$ & 9.0 & 0.56 & 0.89 & 1.45 \\
\hline Top line & $5.36(1.07)$ & 7.0 & 0.14 & 0.63 & 0.77 \\
\hline Weight & $6.69(1.37)$ & 9.0 & 0.34 & 0.84 & 1.18 \\
\hline Chest width & $5.80(1.29)$ & 9.0 & 0.20 & 0.99 & 1.19 \\
\hline Body depth & $6.24(1.05)$ & 7.0 & 0.18 & 0.65 & 0.83 \\
\hline Loin strength & $6.52(1.27)$ & 9.0 & 0.30 & 0.98 & 1.28 \\
\hline \multicolumn{6}{|c|}{ Rump } \\
\hline Rump angle & $5.05(0.93)$ & 5.0 & 0.20 & 0.62 & 0.82 \\
\hline Rump width & $6.56(1.28)$ & 9.0 & 0.37 & 0.81 & 1.18 \\
\hline \multicolumn{6}{|c|}{ Legs and feet } \\
\hline Foot angle & $5.12(1.27)$ & 7.0 & 0.12 & 1.04 & 1.16 \\
\hline Bone quality & $6.35(1.31)$ & 9.0 & 0.26 & 1.11 & 1.36 \\
\hline Side view rear legs & $5.59(1.10)$ & 5.0 & 0.25 & 0.90 & 1.14 \\
\hline \multicolumn{6}{|c|}{ Front udder } \\
\hline Fore udder attachment & $5.85(1.53)$ & 9.0 & 0.36 & 1.56 & 1.92 \\
\hline Fore teat placement & $5.22(1.03)$ & 5.0 & 0.36 & 0.65 & 1.01 \\
\hline Teat length & $6.36(1.22)$ & 5.0 & 0.26 & 0.96 & 1.21 \\
\hline \multicolumn{6}{|c|}{ Rear udder } \\
\hline Rear udder height & $5.77(1.48)$ & 9.0 & 0.25 & 1.26 & 1.51 \\
\hline Rear udder width & $4.36(1.17)$ & 9.0 & 0.34 & 0.87 & 1.21 \\
\hline Rear teat placement & $6.34(1.17)$ & 5.0 & 0.22 & 0.92 & 1.15 \\
\hline \multicolumn{6}{|c|}{ Mammary system } \\
\hline Udder depth & $4.85(1.19)$ & 5.0 & 0.23 & 0.84 & 1.07 \\
\hline Udder texture & $6.52(1.22)$ & 9.0 & 0.11 & 0.92 & 1.03 \\
\hline Udder cleft & $6.30(1.44)$ & 9.0 & 0.35 & 1.33 & 1.68 \\
\hline \multicolumn{6}{|c|}{ Dairy form } \\
\hline Angularity & $6.44(1.21)$ & 9.0 & 0.22 & 0.75 & 0.97 \\
\hline Final score & $81.12(3.47)$ & $>80$ & 1.31 & 5.39 & 6.70 \\
\hline
\end{tabular}

ideal and is also supported by the value of 80 points found by Freitas et al. (2002). This high final score indicates that there is a certain harmony between the 21 type traits, from which the functionality, disease resistance and longevity of the national herd of cows can be inferred.

Estimates of (co)variance (Table 2) are required for genetic evaluation or possible formation of a selection index of the animals of this breed in Brazil. An update of these estimates should be performed periodically to identify possible variations caused by changes in the selection process over time.

Most estimates of heritability were higher than 0.17 (Figure 1) and resemble the results observed in the literature for Holstein herds in countries like Australia, USA and Canada (Thompson et al., 1983; Misztal et al., 1992; Short \& Lawlor, 1992; Van Dorp et al., 1998).

The magnitudes of these values indicate that a considerable proportion of the phenotypic variation occurs due to differences in genes with additive effects and that there may be genetic gains in response to selection procedures.

The traits that showed the highest heritability and therefore would show greater responses to selection in breeding programs are stature $(0.39)$ and fore teat placement (0.36). These values confirm those reported by Misztal et al. (1992) and Darili et al. (2008) to stature (0.42 and 0.38, respectively) and Rupp \& Boichard (1999) to fore teat placement (0.30).

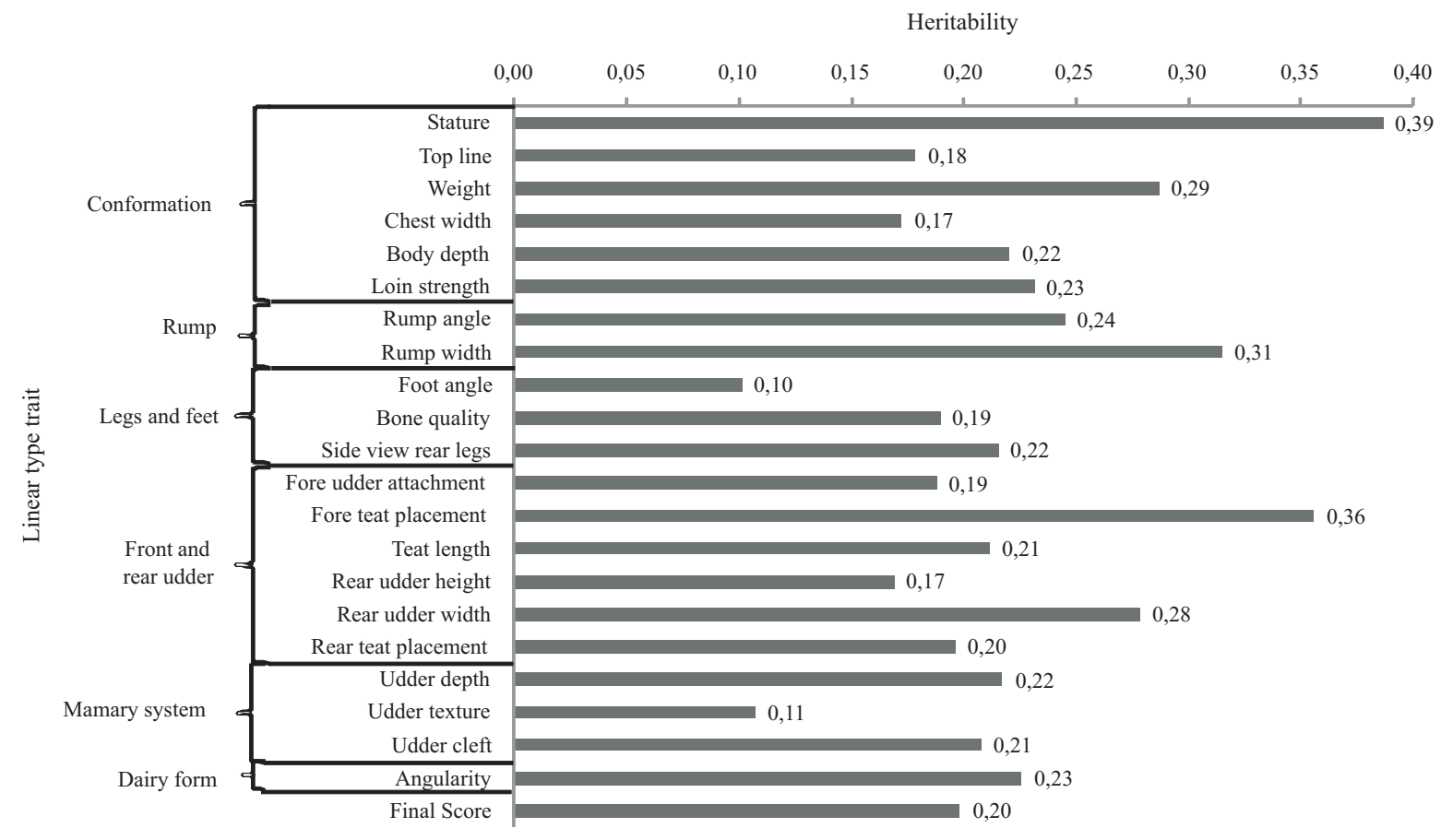

Figure 1 - Estimates of heritability for type traits of Holstein cows. 


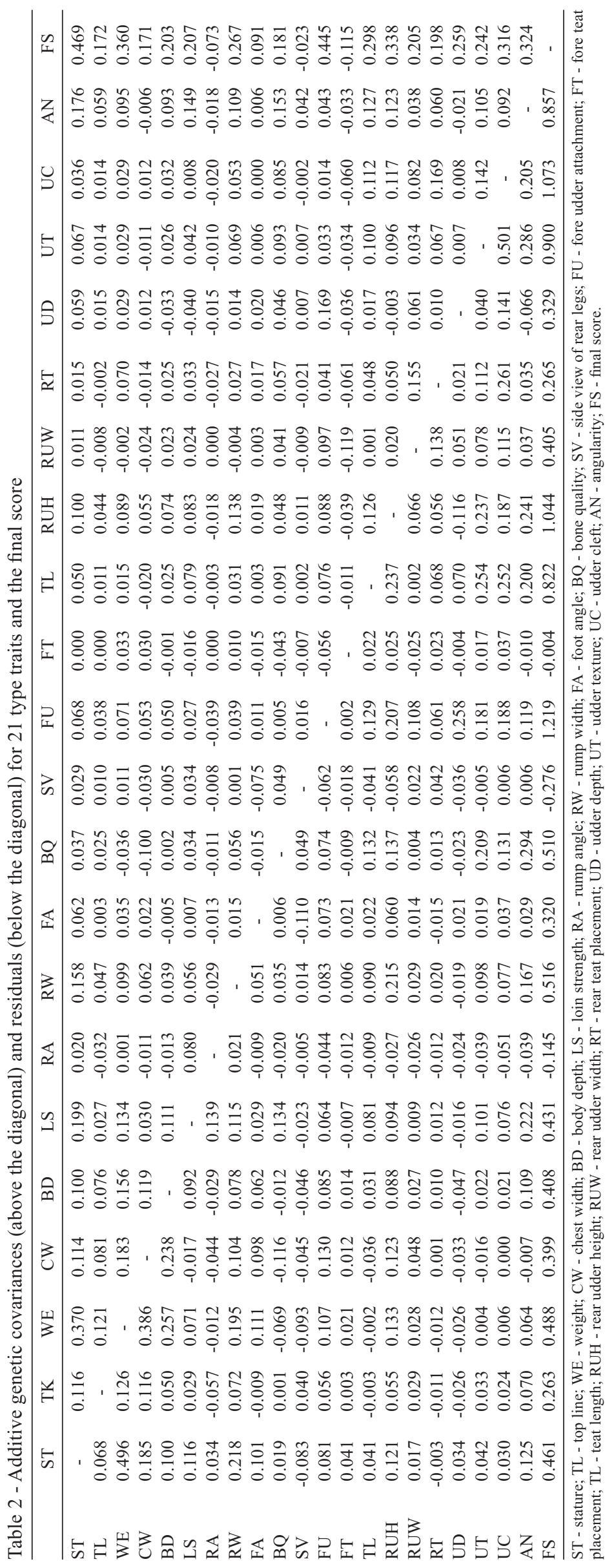

R. Bras. Zootec., v.41, n.10, p.2150-2161, 2012 
The lowest heritability $(0.10$ and 0.11$)$ estimated for the foot angle and udder texture traits were similar to those described by Short et al. (1991), indicating that little response to selection could be expected in these traits. This result shows the importance of environmental effects and non-additive genetic effects in the total variation of these traits. An example may be the influence of some environmental factors on the foot angle, like trimming, and the quality or type of bed to which cows are subjected. In this sense, management improvements (environmental) may be faster ways of changing the mean scores of these in herds.

A heritability of 0.20 for the final score suggests that, in general, moderate responses to selection can be achieved for various type traits. The final score reflects the genetic harmony between the 21 type traits and suggests that these traits can be used as selection criteria to promote improvements in various type traits. It is noteworthy that this estimate was lower than those obtained in previous studies by Thompson et al. (1983) and Short \& Lawlor (1992) for herds of Holstein cows, who reported values of 0.28 and 0.26 , respectively.

According to Rennó et al. (2003), estimates of the heritability of type traits can vary significantly according to breed, population size, the classification system and the model used, so comparisons between studies should be undertaken with caution. Updated knowledge of these estimates in a population should be acquired periodically to identify possible alterations caused by important changes in the selection process over time.

In Brazil, the most recent study with Holstein cows used the univariate model to estimate the heritability of mammary systems and udder traits and the final score (Freitas et al., 2002).

According to Pollak et al. (1984), the use of multiple trait models increases the accuracy of estimates of genetic parameters and can result in significant economic effects on the evaluation of large populations. This increase in accuracy occurs mainly in lower heritability traits, as the analysis uses information from genetic and residual correlations between traits (Mrode \& Thompson, 2005).

The estimates of residual correlations between linear type traits ranged from -0.13 to 0.57 (Table 3 ), and most values were close to null, suggesting that, in general, these traits are not influenced by the same factors or by environmental effects. An exception was observed between weight and the stature (0.57) and chest width (0.42) traits; between udder texture and udder cleft ( 0.45$)$; and between most linear type traits with the final score.
The values obtained for the phenotypic correlations between most type traits, especially those sections related to the rump and legs and feet, were of low magnitude (Table 3). In the section conformation, larger phenotypic associations can be observed between weight and the stature (0.66), chest width (0.48) and body depth (0.42) traits, suggesting that heavier cows also have greater chest width and body depth.

For dairy form, a phenotypic correlation equal to or greater than 0.30 was observed between angularity and the loin strength, bone quality, teat length, rear udder height and udder texture traits, indicating genetic and environmental dependency between them. A similar trend was also reported by Misztal et al. (1992), Short \& Lawlor (1992), McManus \& Saueressig (1998) and Esteves et al. (2004b).

The phenotypic correlations between the final score and 21 linear type traits showed values ranging from -0.11 to 0.46 (Table 3 ). Although with negative values, the rump angle (-0.09), side view of rear legs $(-0.11)$ and fore teat placement $(-0.05)$ traits showed a favorable phenotypic association with the final score. In such cases, higher scores do not indicate the superiority of cows, once intermediate scores are the most desirable.

The magnitude of genetic correlations between type traits ranged from low to high, where the highest correlations were observed between the traits of the section conformation (Figure 2), following the trend of the phenotypic correlations.

In this section, high and positive $(>0.60)$ genetic correlations were observed between the traits of stature and weight (0.85), weight and chest width (0.71), weight and body depth (0.63) and chest width and body depth (0.62). These results indicate that selection for heavier cows would indirectly result in more muscular progeny, with greater body depth and wider chests.

It is noteworthy that the selection for weight may not be favorable due to the fact that, in some cases, the sale of cull cow may not cover this category of animals (Martins et al., 2003).

DeGroot (2002) and Esteves et al. (2004b) also showed the highest genetic correlations between traits of the conformation section, and questioned the need to evaluate the two traits in the same animal, which would result in greater flexibility at the time of collecting in the field and therefore save financial resources. For example, considering the genetic correlation of 0.85 , classifying cows only by height rather than weight seems to be the most viable option, since it is a trait of easy measurement and high heritability. 


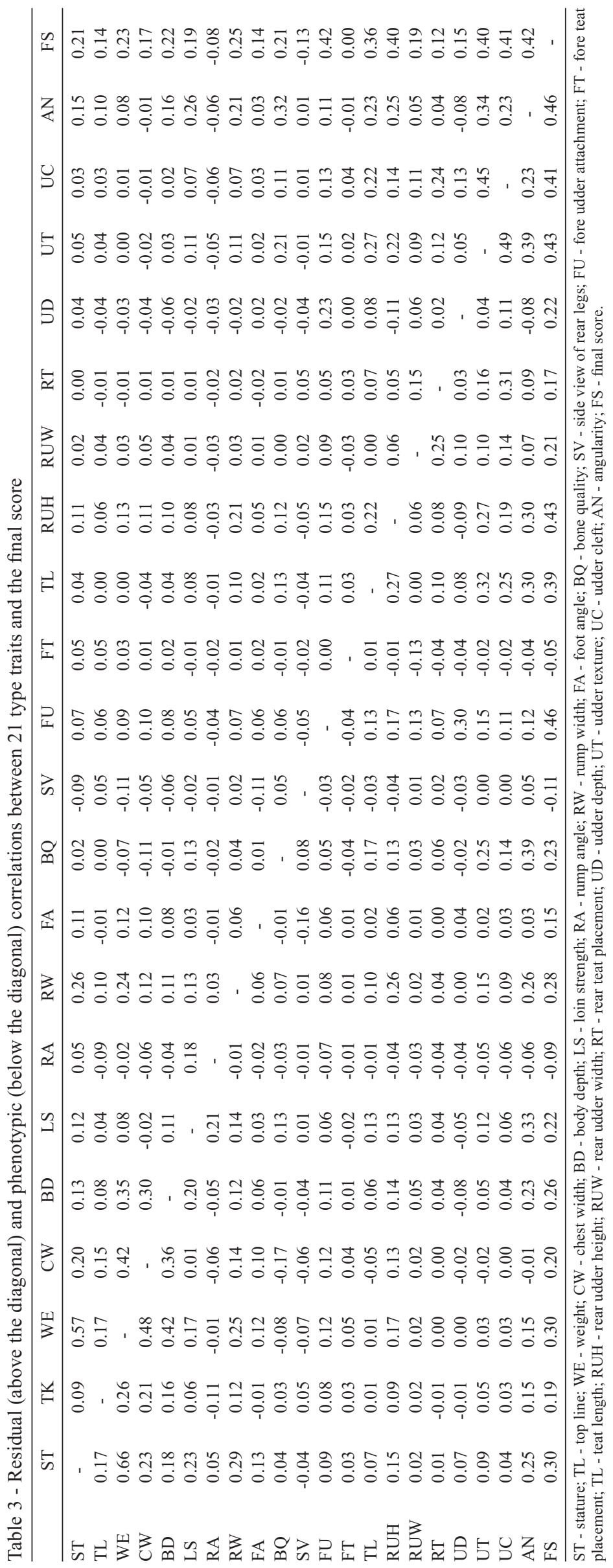


Overall, the conformation traits were positively correlated with other traits of type, except for chest width, which was negatively correlated with eight traits of the other sections, but at low magnitude (Figure 2). The traits of the conformation section showed a genetic correlation equal to or lower than 0.33 with the final score, suggesting, for example, that the use of bulls or semen from top bulls in terms of the final score may facilitate the response to selection for stature, weight, body depth, top line, chest width and loin strength.

Genetic correlations between the traits of the rump section (rump angle and rump width) and legs and feet

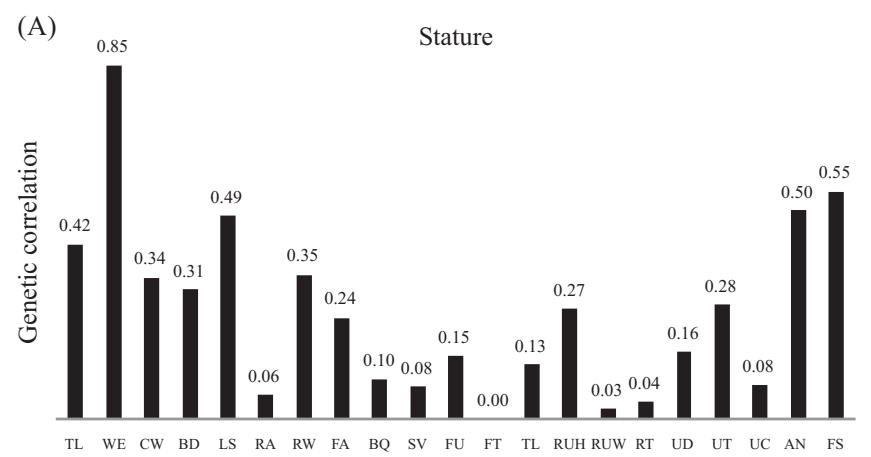

(A)

Type traits

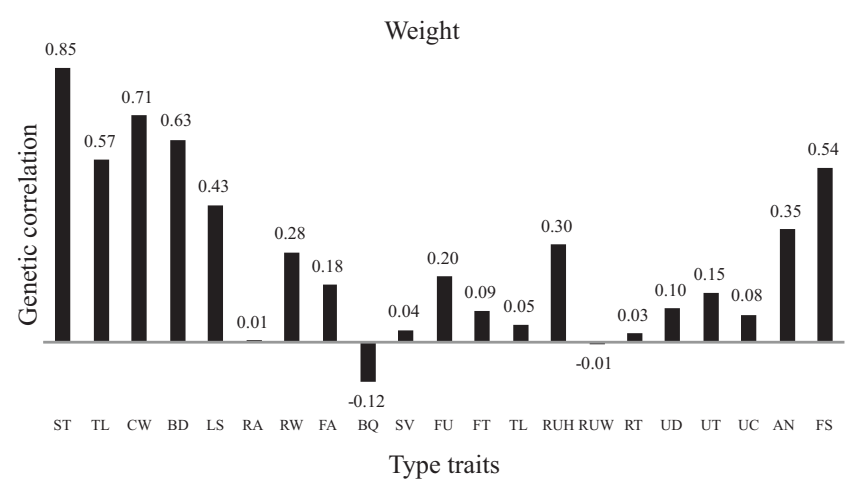

(A)

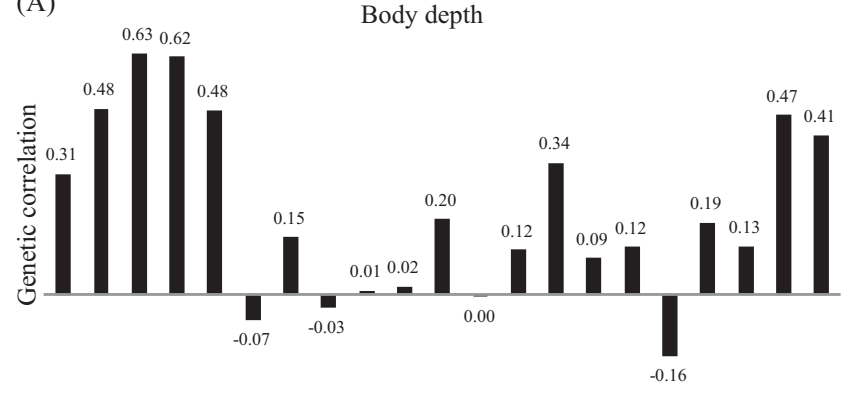

Type traits (foot angle, bone quality and side view of rear legs) showed no definite trend, with correlations generally ranging from low and negative to positive and moderate, with many values close to null (Figure 3 ).

An exception within these two sections was observed for bone quality, which showed a significant genetic correlation with the angularity and udder texture, suggesting that cows that have better angularity also have better bone quality and better udder texture. These results are similar to those observed by Esteves et al. (2004b), in Brazil, who obtained values of 0.56 and 0.66 for genetic

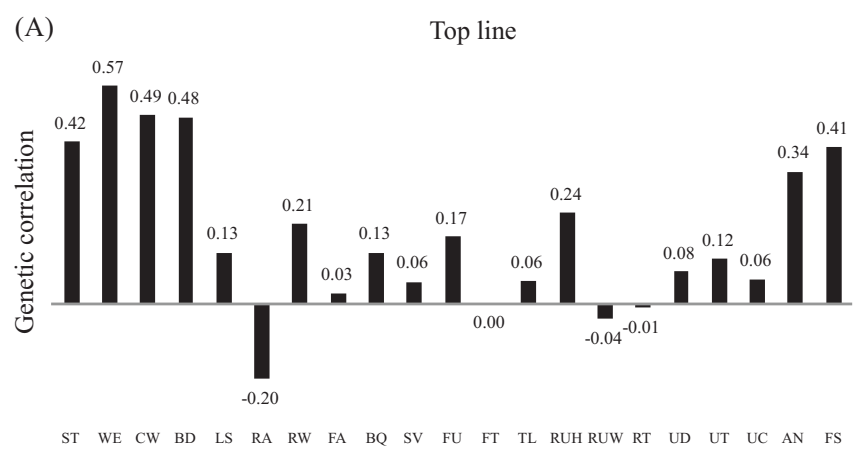

Type traits

(A)

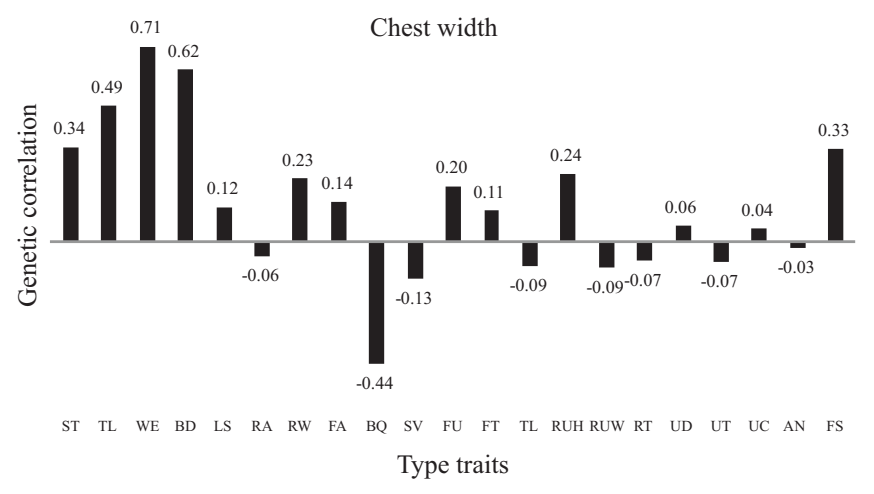

(A)

Loin strength

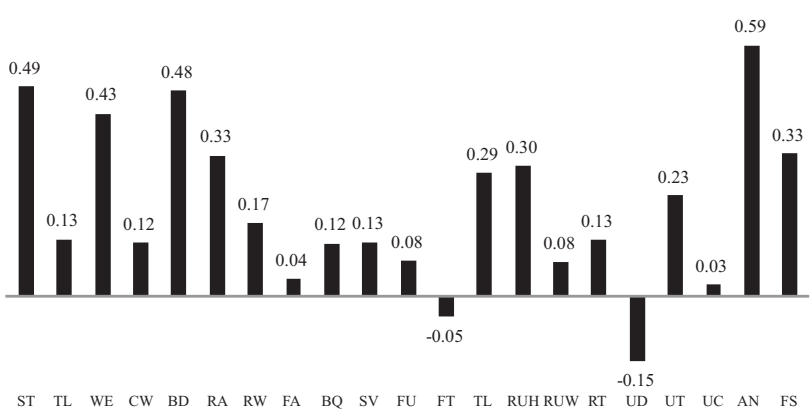

Type traits

ST - stature; TL - top line; WE - weight; CW - chest width; BD - body depth; LS - loin strength; RA - rump angle; RW - rump width; FA - foot angle; BQ - bone quality; SV - side view of rear legs; FU - fore udder attachment; FT - fore teat placement; TL - teat length; RUH - rear udder height; RUW - rear udder width; RT - rear teat placement; UD - udder depth; UT - udder texture; UC - udder cleft; AN - angularity; FS - final score.

Figure 2 - Genetic correlations between conformation traits of the section (A) and other type traits, along with the final score. 
correlations between bone quality and the angularity and udder texture traits, respectively. Moderate to high correlations indicate that the genes responsible for the expression of these traits are probably the same.

Furthermore, the negative genetic correlation between rump width and the foot angle, bone quality and side view of rear legs with other traits of type (Figure 3) suggests that selection for any of these can result in genetic gains undesirable in other traits. The most significant negative genetic correlations in this section were observed between bone quality and chest width and between the leg position

(B)

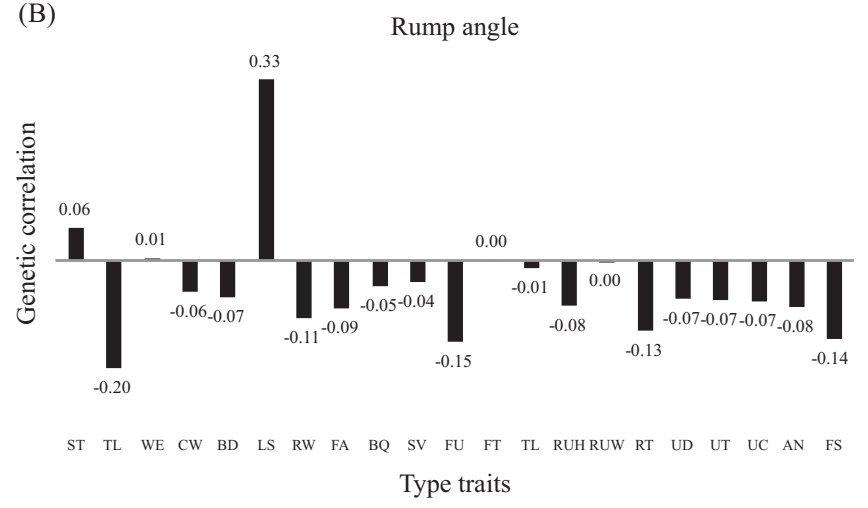

(C)

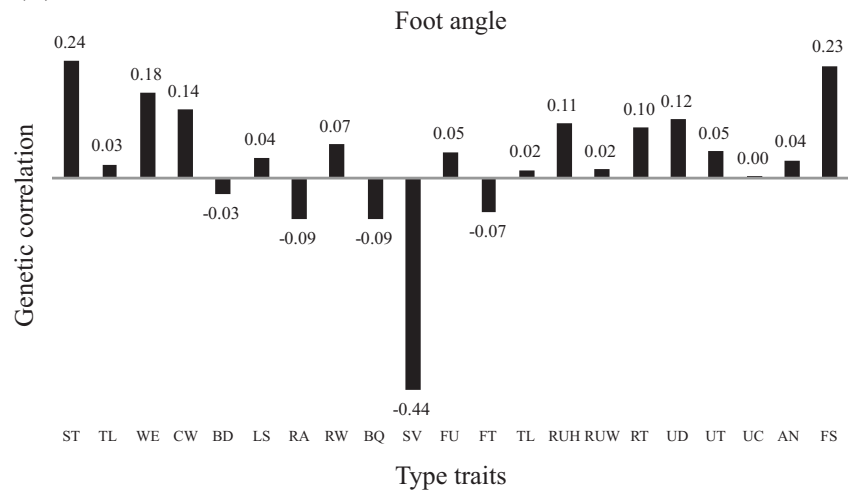

and the foot, both with a value of -0.44 , in agreement with values obtained by Esteves et al. (2004b).

The genetic correlation between these traits indicates that the use of sires with high genetic values for chest width generate progeny with poor bone quality, and that those with high genetic values for foot angle tend to have daughters with sharply straight legs.

In heterogeneous conditions of relief, cows with less inclined hooves demonstrate good bone quality, which would consequently lead to an improved gait due to the correct side view of rear legs, making the cow more

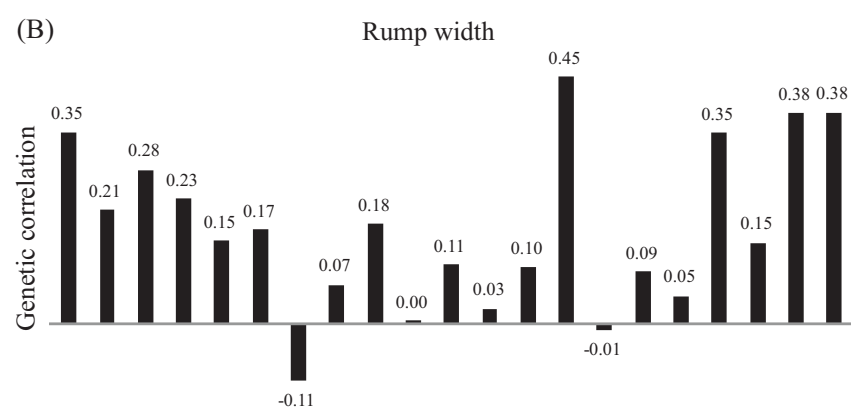
ST TL WE CW BD LS RA FA BQ $\quad$ SV FU FT TL RUH RUW RT UD UT UC AN FS Type traits

(C)

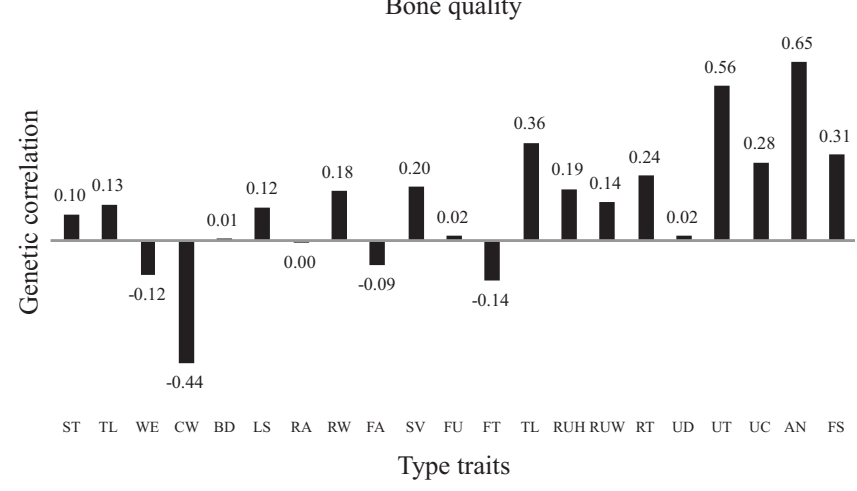

(C) Side view of rear legs

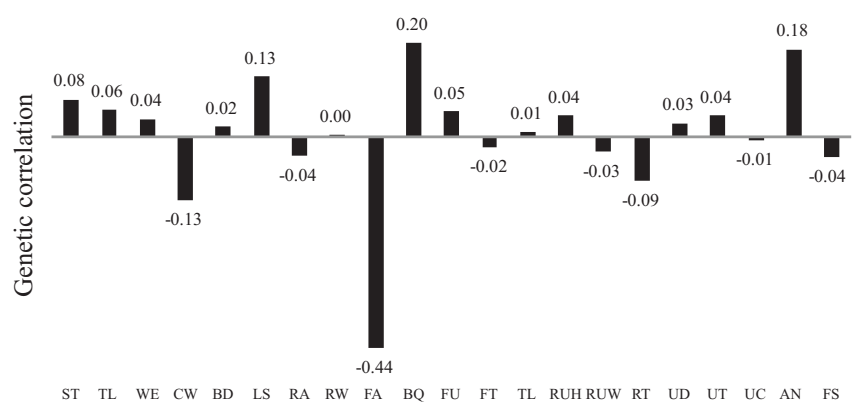

Type traits

ST - stature; TL - top line; WE - weight; CW - chest width; BD - body depth; LS - loin strength; RA - rump angle; RW - rump width; FA - foot angle; BQ - bone quality; SV - side view of rear legs; FU - fore udder attachment; FT - fore teat placement; TL - teat length; RUH - rear udder height; RUW - rear udder width; RT - rear teat placement; UD - udder depth; UT - udder texture; UC - udder cleft; AN - angularity; FS - final score.

Figure 3 - Genetic correlations between traits of sections rump (B) and legs and feet (C) with other type traits, plus the final score. 
functional and thus reducing the likelihood of its being discarded, as stressed by Sewalem et al. (2004).

The moderate and positive values for genetic correlations between the final score and foot angle (0.23), hump width $(0.38)$ and bone quality $(0.31)$ indicate that selection for the first trait leads to a slight improvement in the three genetic final following traits (Figure 3). The same cannot be said for the side view of rear legs and rump angle. This situation shows the complexity of selection of the best bulls (or semen) to improve more than one type trait. Therefore, in the selection for a greater final score, traits that express a balance

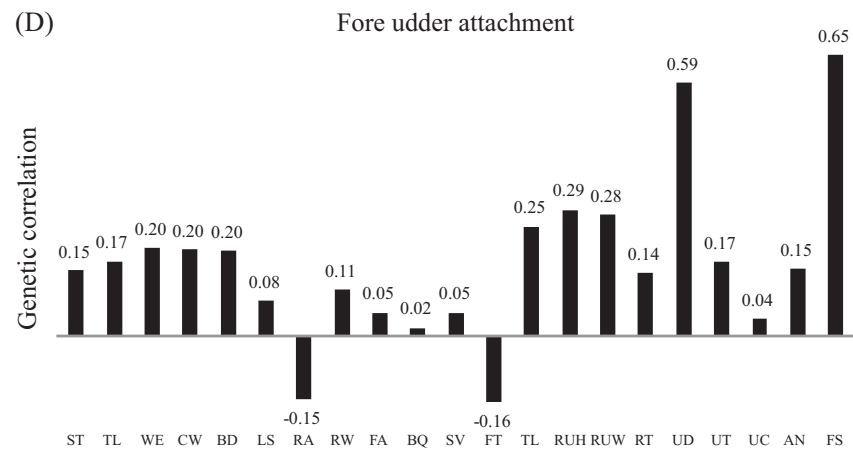

Type traits

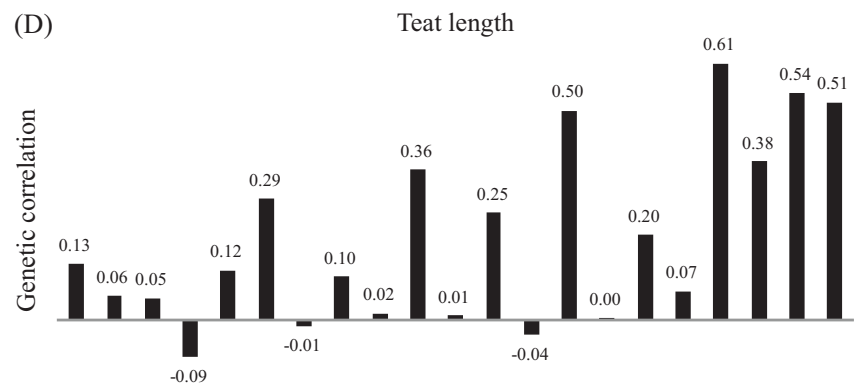

ST TL WE CW BD LS RA RW FA BQ SV FU FT RUH RUW RT UD UT UC AN FS

Type traits

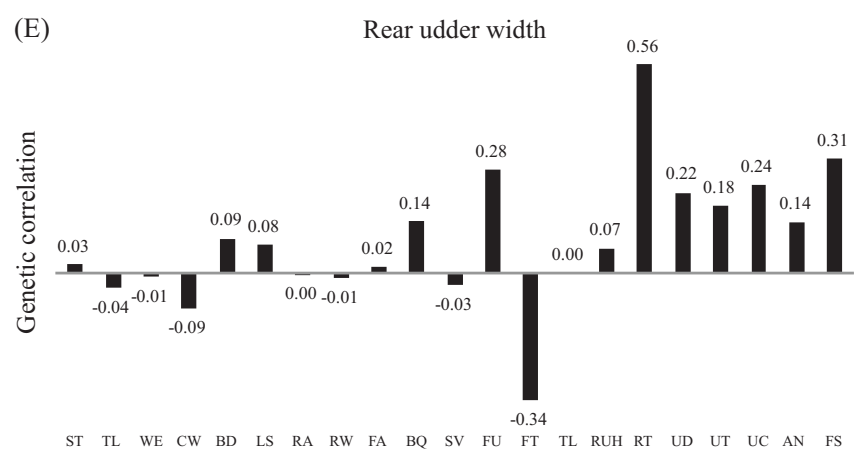

Type traits between all the type traits do not always lead to significant genetic gains and favorable values in all type traits.

In the front udder section, fore teat placement showed a negative genetic association with all the traits sections of the legs and feet, front and rear udder, the mammary system and dairy form (Figure 4). This is corroborated by a report from Sewalem et al. (2004), showing the important influence of udder traits in the decision related to involuntary culling of cows.

As opposed to what was observed for fore teat placement, positive genetic correlations were observed

(D)

Fore teat placement

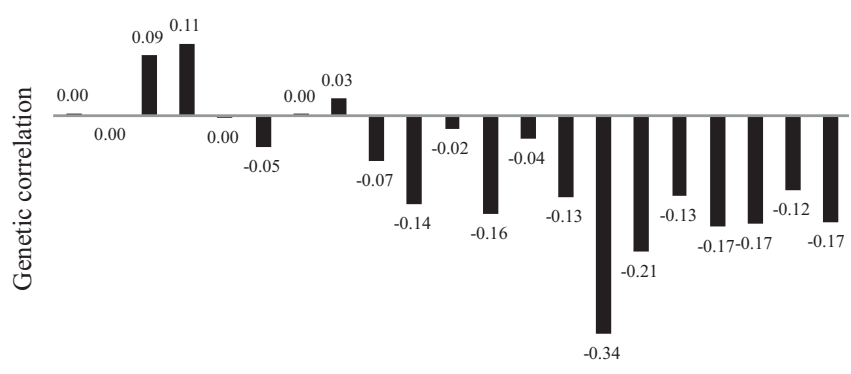

Type traits

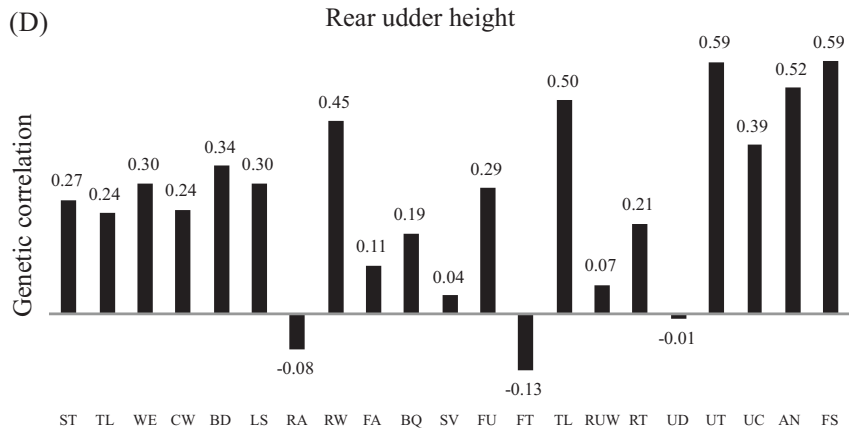

Type traits

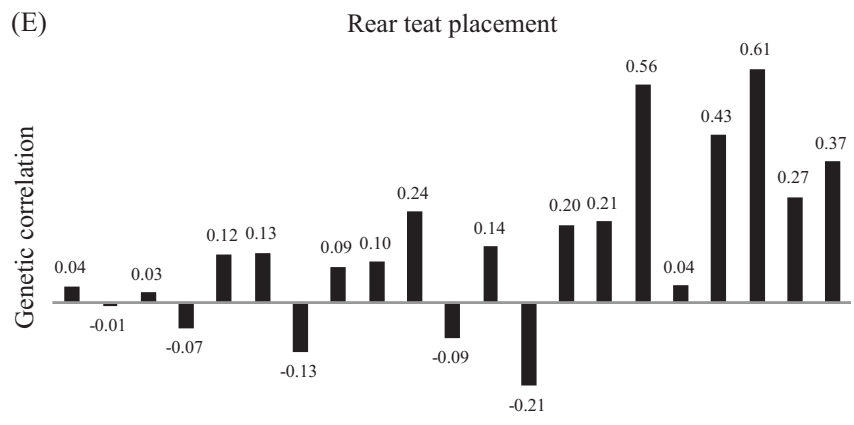

Type traits

ST - stature; TL - top line; WE - weight; CW - chest width; BD - body depth; LS - loin strength; RA - rump angle; RW - rump width; FA - foot angle; BQ - bone quality; SV - side view of rear legs; FU - fore udder attachment; FT - fore teat placement; TL - teat length; RUH - rear udder height; RUW - rear udder width; RT - rear teat placement; UD - udder depth; UT - udder texture; UC - udder cleft; AN - angularity; FS - final score.

Figure 4 - Genetic correlations between fore (D) and rear udder (E) traits with other type traits, plus the final score. 
between fore udder attachment and teat length to the traits of the rear udder section, the mammary system and dairy form (Figure 4), with high values for correlations between the traits of fore udder attachment and udder depth (0.59); teat length and udder texture (0.61); rear teat placement and udder cleft (0.61); and rear udder height and the udder texture (0.59).

It is noteworthy that although a significant genetic association between teat length and udder texture or between rear teat placement and udder cleft are unfavorable to the targets of selection, this again emphasizes the complexity

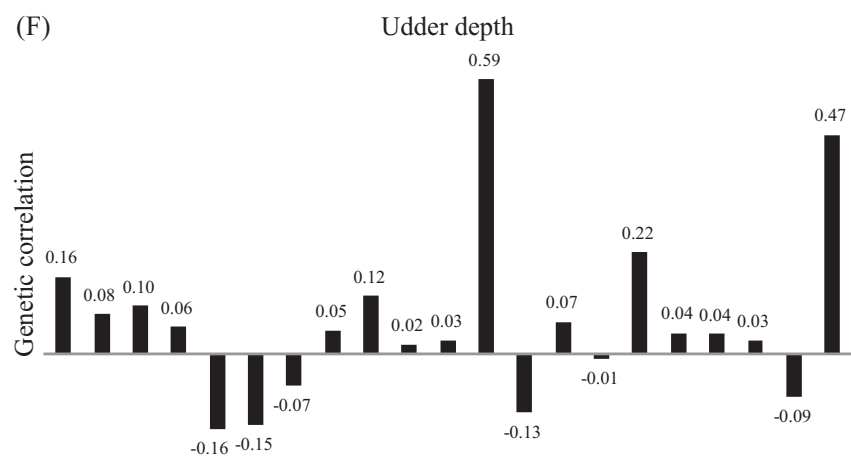
ST TL WE CW BD LS RA RW FA BQ SV FU FT TL RUHRUW RT UT UC AN FS Type traits

(F)

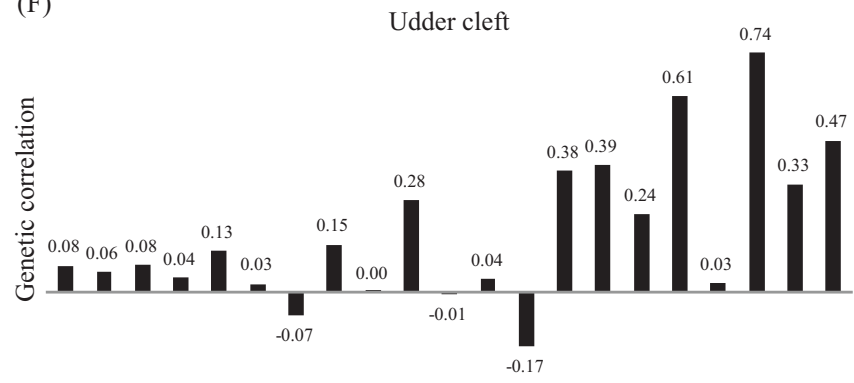

ST TL WE CW BD LS RA RW FA BQ SV FU FT TL RUH RUW RT UD UT AN FS Type traits of the selective procedure to obtain a simultaneous improvement of the type trait.

For the rear udder section, the rear udder height showed positive correlations ranging from moderate to high with most traits (Figure 4), except for the rump angle (-0.09), fore teat placement $(-0.18)$ and udder depth (-0.01).

Regarding the correlations between the final score and traits present in the fore udder and rear udder sections (Figure 5), moderate and high genetic correlations were observed between the traits, especially in the traits of the

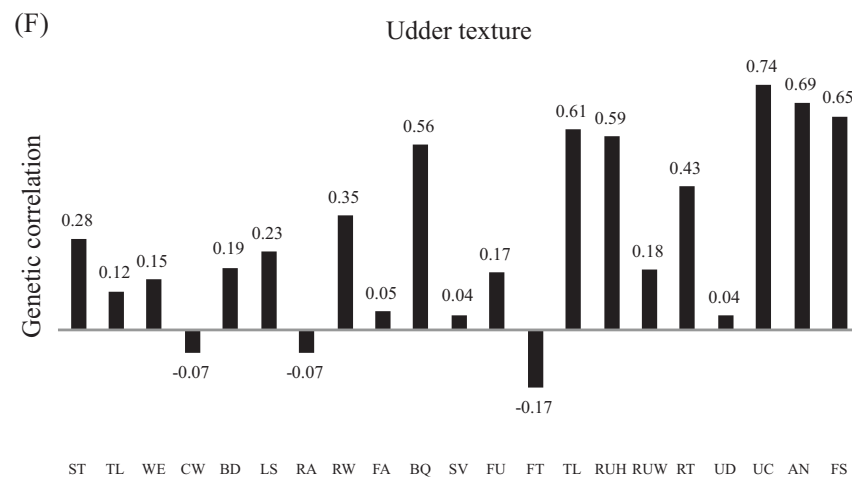

Type traits

(G)

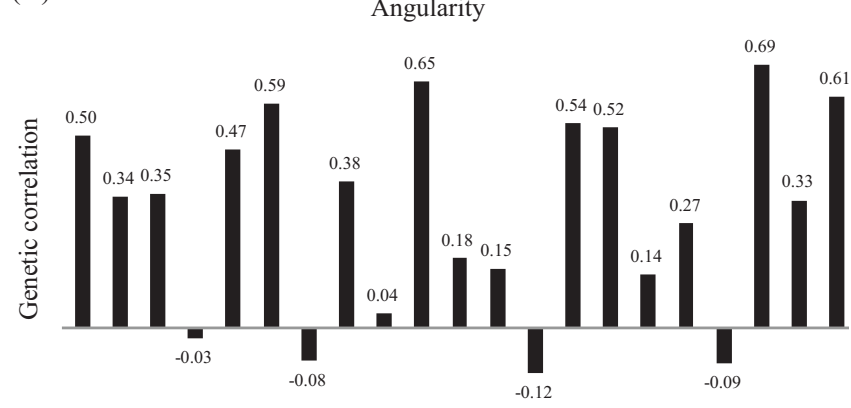

Type traits

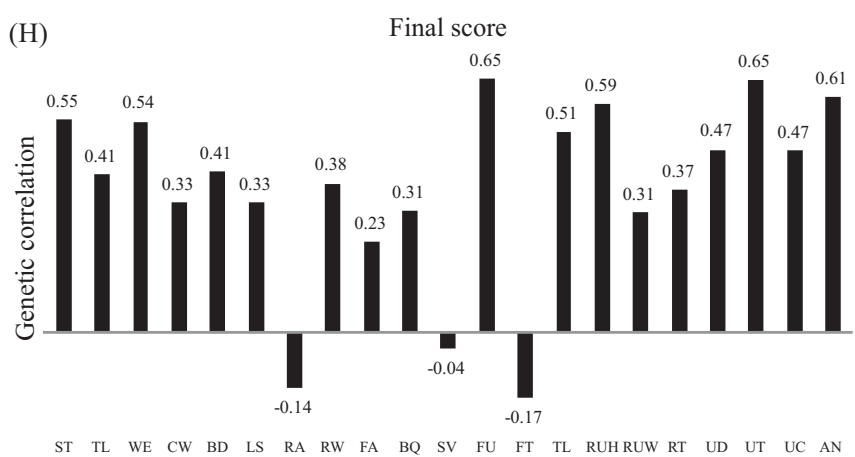

Type traits

ST - stature; TL - top line; WE - weight; CW - chest width; BD - body depth; LS - loin strength; RA - rump angle; RW - rump width; FA - foot angle; BQ - bone quality; SV - side view of rear legs; FU - fore udder attachment; FT - fore teat placement; TL - teat length; RUH - rear udder height; RUW - rear udder width; RT - rear teat placement; UD - udder depth; UT - udder texture; UC - udder cleft; AN - angularity; FS - final score.

Figure 5 - Genetic correlations between traits of the mammary system section $(\mathrm{F})$, dairy form $(\mathrm{G})$ and final score $(\mathrm{H})$ with other type traits. 
mammary system and height, showing that cows with high final scores also showed high scores in most linear type traits.

In general, the traits that make up the mammary system section were positively and genetically correlated with other type traits (Figure 5); the highest correlations were between udder depth and fore udder attachment (0.59) and the udder texture and udder cleft (0.74). Due to the high correlations between traits, one might think that in the classification of cows considering only a few traits, a value of 0.74 for the correlation indicates that approximately $55 \%$ of the variation in the udder texture is explained by the udder cleft trait.

In the section related to dairy form, it was found that angularity has a positive genetic correlation, ranging from moderate to high with the majority of type traits, with the udder texture (0.69) and the bone quality (0.65) showing the strongest correlations with that trait (Figure 5).

This may indicate, for example, that selection for more angular animals would result in progeny of good stature, bone quality and loin strength capable of withstanding a good udder composite, combined with a good body depth, udder texture and desirable teat length and with a high rear udder, improving the life expectancy of the cow, as supported by the genetic relationship between angularity and longevity reported by Sewalem et al. (2004).

Positive genetic correlations, ranging from moderate to high, were found between the final score and most of the type traits (Figure 5), except for the hump angle $(-0.14)$, the side view of rear legs $(-0.04)$ and fore teat placement $(-0.17)$, which showed weak negative genetic correlations.

The genetic correlation between these traits suggests that selection for final score can foster similar responses in several traits, resulting in taller, deeper, and more angular animals, with good udder attachment, a leveled top line, good teat length, height and udder texture. It is noteworthy that cows with high final scores tend to be longer-lived (Schneider et al., 2003; Sewalem et al., 2004), since these traits express a balance in the cow for all type traits; their genetic relationships deserve special attention (Esteves et al., 2004).

It is noteworthy that the positive correlations between fore teat length (0.51) and rear teat placement (0.37) and the trait final score are unfavorable (Figure 5), and a possible focus of selection for higher final scores may result, for example, in cows with teats of greater length.
The unfavorable genetic relationship in the type traits that seems to be present both within and between sections demonstrates the need to practice selection of the national herd of animals with the help of indexes, enabling the producer to select the best bulls (or semen) or cows for type.

Currently, national breed genetic evaluation is performed individually for each type trait and final score without the availability of the genetic merit of bulls (or cows) by an index that involves several traits. The selection index method is used by many countries, and includes traits not only for type but also for reproductive traits, productivity and functionality (longevity, etc.).

According to Short \& Lawlor (1992) and Sewalem et al. (2004), among all the type traits, mammary system traits should receive greater emphasis on selection indexes to provide a positive effect on longevity or increase the productive life of cows, second in importance only to the final score.

The selection of bulls and cows commonly based on estimated breeding values for the final score for the national genetic evaluation of Holstein cows is not entirely feasible, although long-term deterioration may occur, for example in the genetic merit of animals for udder traits (teat length or fore teat placement) because of their unfavorable or disadvantageous genetic relationships. This adverse relationship may be disturbing, since the current selection process has not yet adopted an index, suggesting the need to implement this method in the selection of breed in Brazil.

On the other hand, and considering the need for greater objectivity in the practice of classification of cows by technicians, the values of the correlations suggest the possibility of excluding some traits of the system of linear classification, also aiming to shape the national classification system to the international classification system for dairy cattle recommended by the World Federation of Holsteins (WHFF, 2005).

In this sense, it can be noted that several countries already conduct genetic evaluations of their flocks together with other countries, now called MACE (Multiple Across Country Evaluation). This type of evaluation allows for comparing the classification of the best bulls for each country. It is essential to have a certain standardization of the evaluated traits or linear classification system adopted in different countries that aspire to participate in this type of genetic evaluation. 


\section{Conclusions}

The additive genetic variability observed in type traits can provide moderate genetic gains through selection. High genetic correlations between the various traits are indicative that some of them can be excluded from the linear classification system adopted by the Association of Holstein Breeders. There is an unfavorable genetic relationship between some type traits, either within or between sections. One possible focus of selection for the final score at the expense of other traits must be performed with restraint, because in the long term, this may promote undesirable changes in some type traits.

\section{Acknowledgments}

The authors thank Associação Brasileira de Criadores de Bovinos da Raça Holandesa (ABCBRH) for providing the data and their staff for data collection, thus providing the opportunity to develop this study. The authors also thank Centro Nacional de Processamento de Alto Desempenho em São Paulo (CENAPAD) for providing the computing environment suitable for performing the analysis.

\section{References}

BERRY, D.P.; HARRIS, B.L.; WINKELMAN, A.M. et al. Phenotypic associations between traits other than production and longevity in New Zealand dairy cattle. Journal of Dairy Science, v.88, p.2962-2974, 2005.

DARILI, Z.; HAFEZIAN, S.H.; SHAD PARVAR, A. et al. Genetic relationships among longevity, milk production and linear type traits in Iranian Holstein Cattle. Journal of Animal and Veterinary Advances, v.7, p.512-515, 2008.

DEGROOT, B.J.; KEOWN J.F.; VAN VLECK, L.D.; et al. Genetic parameters and responses of linear type, yield traits, and somatic cell scores to divergent selection for predicted transmitting ability for type in Holsteins. Journal of Dairy Science, v.85, p.1578-1585, 2002.

ESTEVES, A.M.C.; BERGMANN, J.A.G.; DURÃES, M.C. et al. Correlações genéticas e fenotípicas entre características de tipo e produção de leite em bovinos da raça Holandesa. Arquivo Brasileiro de Medicina Veterinária e Zootecnia, v.56, p.529-535, 2004a.

ESTEVES, A.M.C.; BERGMANN, J.A.G.; DURÃES, M.C. et al. Estudo dos efeitos de ambiente sobre as características lineares de tipo em rebanhos bovinos da raça Holandesa. Arquivo Brasileiro de Medicina Veterinária e Zootecnia, v.56, p.522-528, 2004b.

FREITAS, A.F.; TEIXEIRA, N.M.; DURÄES, M.C. et al. Parâmetros genéticos para características lineares de úbere, escore final de tipo, produção de leite e produção de gordura na raça Holandesa. Arquivo Brasileiro de Medicina Veterinária e Zootecnia, v.54, p.485-491, 2002.

KLASSEN, D.J.; MONARDES, H.G.; JAIRATH, L.; et al. Genetics correlations between life production and linearized type in Canadian Holsteins. Journal of Dairy Science, v.75, p.2272-2282, 1992.

LAGROTTA, M.R.; EUCLYDES, R.F.; VERNEQUE, R.S. et al. Relação entre características morfológicas e produção de leite em vacas da raça Gir. Pesquisa Agropecuária Brasileira, v.45, p.423-429, 2010
MARTINS, G.A.; MADALENA, F.E.; BRUSCHI, J.H. et al. Objetivos econômicos de seleção de bovinos de leite para fazenda demonstrativa na Zona da Mata de Minas Gerais. Revista Brasileira de Zootecnia, v.32, p.304-314, 2003.

MCMANUS, C.; SAUERESSIG, M.G. Estudo de características de tipo em gado Holandês em confinamento total no Distrito Federal. Revista Brasileira de Zootecnia, v.27, p.906-915, 1998.

MIGLIOR, F.; MUIR, B.L.; VAN DOORMAAL, B.J. Selection indices in Holstein cattle of various countries. Journal Dairy Science, v.88, p.1255-1263, 2005.

MISZTAL, I.; LAWLOR, T.J.; SHORT, T.H. et al. Multiple-trait estimation of variance components of yield and type traits using an animal model. Journal of Dairy Science, v.75, p.544-551, 1992.

MISZTAL, I. [2001] REML90 Manual. Available at: $<$ http://nce.ads. uga.edu/ ignacy/numpub/blupf90/docs/remlf90.pdf $>$. Accessed on: Sep. 13, 2010.

MRODE, R.A.; THOMPSON, R. Linear models for the prediction of animal breeding values. 2.ed. Cambridge, USA: CABI Publishing, 2005. 344p.

PÉRES-CABAL, M.A.; ALENDA, R. Genetic relationships between lifetime profit and type traits in Spanish Holstein cows. Journal of Dairy Science, v.85, p.3489-3491, 2002.

PÉRES-CABAL, M.A.; GARCIA, C.; GONZALES-RECIO, O. et al. Genetic and phenotypic relationship among locomotion, type traits, profit, production, longevity and fertility in Spanish dairy cows. Journal of Dairy Science, v.89, p.1776-1783, 2006.

POLLAK, E.J.; VAN DER WERF, J.; QUAAS, R.L. Selection bias and multiple trait evaluation. Journal of Dairy Science, v.67, p.1590-1595, 1984.

PRIBYL, J.; ک̌AFUS, P.; ŠTÍPKOVÁ, M. et al. Selection index for bulls of Holstein cattle in the Czech Republic. Czech Journal Animal Science, v.49, p.244-256, 2004

RENNÓ, F.P.; ARAÚJO, C.V.; PEREIRA, J.C. et al. Correlações genéticas e fenotípicas entre características de conformação e produção de leite em bovinos da raça Pardo-Suíça no Brasil. Revista Brasileira de Zootecnia, v.32, p.1419-1430, 2003.

RUPP, R.; BOICHARD, D. Genetic parameters for clinical mastitis, somatic cell score, production, udder type traits, and milking ease in first lactation Holsteins. Journal of Dairy Science, v.82, p.2198-2204, 1999

SBRISSIA, G.F. Sistema agroindustrial do leite: custos de transferência e preços locais. 2005. 58f. Dissertação (Mestrado em Ciências) - Escola Superior de Agricultura "Luiz de Queiroz"/ Universidade de São Paulo, Piracicaba.

SCHNEIDER, M.; DEL, P.J.; DURR, W. et al. Impact of type traits on functional herd life of Quebec Holsteins assessed by survival analysis. Journal of Dairy Science. v.86, p.4083-4089, 2003.

SEWALEM, A.; KISTEMAKER, G.J.; MIGLIOR, F. et al. Analysis of the relationship between type traits and functional survival in Canadian Holsteins using a Weibull proportional hazards model. Journal of Dairy Science, v.87, p.3938-3946, 2004.

SHORT, T.H.; LAWLOR, T.J.; LEE, K.L. Genetic parameter for three experimental linear type traits. Journal of Dairy Science, v.74, p.2020-2025, 1991

SHORT, T.H.; LAWLOR, T.J. Genetic parameters of conformation traits, milk yield, and herd life in Holstein. Journal of Dairy Science, v.75, p.1978-1998, 1992.

THOMPSON, J.R.; LEE, K.L.; FREEMAN, A.E. et al. Evaluation of a linearized type appraisal system for Holstein cattle. Journal of Dairy Science, v.66, p.325-331, 1983

VAN DORP, T.E.; DEKKERS, J.C.M.; MARTIN, S.W. et al. Genetic parameters of health disorders, and relationships with 305-day milk yield and conformation traits of registered Holstein cows. Journal of Dairy Science, v.81, p.2264-2270, 1998.

WHFF [2005]. Evaluación morfológica internacional del vacuno de letche. World Holstein Friesian Federation. Available at: <http:// www.whff.info/info/typetraits.php>. Accessed on: Dec. 10, 2011.

WIGGANS, G.R.; GENGLER, N.; WRIGHT, J.R. Type trait (co)variance components for five dairy breeds. Journal of Dairy Science, v.87, p.2324-2330, 2004. 